\title{
Risk Factors for Pregnancies Among Females Age 15 to 19 in Rwanda: A Secondary Data Analysis of the 2014/2015 Rwanda Demographic and Health Survey (RDHS)
}

\author{
Dieudonne Hakizimana ${ }^{1}$, Jenae Logan ${ }^{1} \&$ Rex Wong ${ }^{1}$ \\ ${ }^{1}$ University of Global Health Equity, Rwanda \\ Correspondent: Dieudonne Hakizimana, University of Global Health Equity, Rwanda. Tel: 250-788-316-894.
}

Received: January 12, 2019

Accepted: March 7, 2019

Online Published: March 11, 2019

doi:10.5430/jms.v10n2p49

URL: https://doi.org/10.5430/jms.v10n2p49

\begin{abstract}
Teenage pregnancy is a significant public health problem in developing countries. Due to biological and social factors, teenagers have more negative health outcomes when pregnant. Pregnancy also causes teenagers to drop-out from school, affecting their job opportunities and long-term financial security. As the risk factors for teenage pregnancies are complex and context-specific, effective strategies to reduce teenage pregnancies must be informed by evidence.

This study analyzed the data collected by the 2014-2015 Rwanda Demographic and Health Survey in Rwanda. The risk factors associated with 2768 females aged between 15-19 years in the dataset were identified using logistic regression.

The overall teenage pregnancy rate was $7.3 \%$. Teens were more likely to have a teenage pregnancy if they were 17 years old $(\mathrm{OR}=7.04,95 \% \mathrm{CI}: 2.67-18.58, \mathrm{p}<0.001), 18$ years old $(\mathrm{OR}=3.78,95 \% \mathrm{CI}: 1.36-10.47, \mathrm{p}=0.011)$, and 19 years old $(\mathrm{OR}=3.85,95 \% \mathrm{CI}: 1.34-11.01, \mathrm{p}=0.012)$ compared to teens under 16 years old. Those with secondary or higher education $(\mathrm{OR}=0.36,95 \% \mathrm{CI} 0.22-0.61, \mathrm{p}=<0.001)$ were less likely to have a teenage pregnancy compared to those with primary school only. Teens had higher odds to have teenage pregnancy if they were married/in union $(\mathrm{OR}=45.9,95 \% \mathrm{CI}: 21.34-98.73, \mathrm{P}<0.001)$, and interestingly, if they were using contraceptive methods $(\mathrm{OR}=68.9$, 95\% CI: 29.49 - 160.80, $\mathrm{P}<0.001)$.

Policy makers should consider programs keeping girls in schools and ensuring that teenagers have access to reproductive health information and reliable contraceptive methods at an early age. Teenage marriage should be discouraged.
\end{abstract}

Keywords: teenage pregnancy, women of reproductive age, adolescent health, prevalence, associated factors, sexual and reproductive health

\section{Introduction}

Teenage pregnancy is a worldwide public health problem with unequal associated burden distribution across high and low income countries; it is estimated that $95 \%$ of births among adolescents occur in low- and middle-income countries (LMIC) (UNFPA, 2013a).

As a result of their age and physical development, pregnant teenagers, are more likely to have premature labor, anemia, pre-eclampsia, low birth weight babies, and stillbirth (Ertem, Saka, Ceylan, Değer, \& Çiftçi, 2008; Loto et al., 2004). Many teenagers also have limited access to medical services, resulting in using unsafe procedures - around 3.9 million teenage women undergo unsafe abortions and about 70,000 die due to various pregnancy- and childbirth-related complications in LMICs every year (UNFPA, 2013b). They are also more susceptible to depression and sexually transmitted infections (Coelho et al., 2013). Teenage pregnancy is also associated with higher risks of dropping out of school and subsequently with fewer job opportunities, affecting earning power and long term financial security (Brace, Hall, Eatman, \& Tucker, 2008; Ganchimeg et al., 2014; UNFPA, 2013b).

Existing evidence suggests a long list of possible risk factors contributing to teenage pregnancies, including low education level, lack of negotiation skills, insufficient parental supervision, not using contraceptive methods, age at marriage, religion, residing in rural versus urban areas, peer pressure, and lower economic status (Ajala, 2014; 
Christofides et al., 2014; Kanku \& Marsh, 2014; Moni, Nair, \& Devi, 2013; Neal, Chandra-Mouli, \& Chou, 2015; Okigbo \& Speizer, 2015; Rutaremwa, 2013). In addition, teenagers living in households headed by single females or in families with poor family relationships are at higher risk of getting pregnant (Odimegwu \& Mkwananzi, 2016).

Various strategies to address teen pregnancy, from encouraging abstinence to improving access to contraceptives, have been met with mixed results in LMICs (DiCenso, Guyatt, Willan, \& Griffith, 2002; Kohler, Manhart, \& Lafferty, 2008; Neal et al., 2015; Oringanje et al., 2016; Stanger-Hall \& Hall, 2011), suggesting that effective strategies must consider the differences in settings, cultures, religious beliefs and community perceptions (Chandra-Mouli, McCarraher, Phillips, Williamson, \& Hainsworth, 2014; Iwu, Onoja, Ijioma, Ngumah, \& Egeruoh, 2011).

The latest Rwanda Demographic and Health Survey (RDHS 2014-15) found that teenage pregnancy rate had increased from $4.1 \%$ in 2005 to $7.3 \%$ in 2015, with the rate in some regions reaching as high as $15.8 \%$ (National Institute of Statistics of Rwanda (NISR), Ministry of Health (MOH) [Rwanda], 2015). While many studies have used DHS data to study risk factors related to antenatal care, postnatal care, fertility, and nutrition (Manzi et al., 2014; Mukabutera et al., 2016; Ndahindwa et al., 2014), none have studies those related to teenage pregnancies in Rwanda. Accordingly, this study utilized a secondary data analysis method to identify the risk factors contributing to teenage pregnancies in Rwanda. The results of this study will inform the development of appropriate interventions to reduce teenage pregnancy.

\section{Materials and Methods}

\subsection{Study Setting}

Rwanda had an estimated population of $10,515,973$ in 2012 , of which $51.8 \%$ were female and $23.4 \%$ were at reproductive age (National Institute of Statistics of Rwanda, 2014); with a 2.6\% population growth rate and 748.4 USD GDP per capita (National Institute of Statistics of Rwanda, 2014; The World Bank Group, 2017). Rwanda has demonstrated marked improvement in maternal health over the past 20 years: between 2000 and 2015, the maternal mortality rate fell from 1,071 to 210 per 100,000 live births and total fertility rate fell from 6.1 to 4.2 (Binagwaho et al., 2014; National Institute of Statistics of Rwanda (NISR), Ministry of Health (MOH) [Rwanda], 2015). In 2015, 53\% of people used contraception, 99\% of pregnant women attended at least one antenatal care session, and $91 \%$ of deliveries took place at the health facility (National Institute of Statistics of Rwanda (NISR), Ministry of Health (MOH) [Rwanda], 2015). The teenage pregnancy rate, however, has recently increased.

\subsection{Data}

This study analyzed the data of 2014/2015 Rwanda Demographic and Health Survey (RDHS). The RDHS is a national survey that is conducted every five years to provide a broad range of demographic, health, and social data to monitor the population and health situation in Rwanda (National Institute of Statistics of Rwanda (NISR), Ministry of Health (MOH) [Rwanda], 2015). The RDHS has multiple datasets based on different survey units including household, birth, children, men, and women. The dataset this study analyzed was the women database. The database contained information of 13,497 women, of which 2,779 women were between the age of 15 and 19 years. After adjusting sampling weights for the effects of the stratification and cluster sampling approaches, there were 2,768 women included in the analysis.

\subsection{Variables}

\subsubsection{Dependent Variables}

The dependent variable was teenage pregnancy, defined as a woman aged 15-19 years who has ever had a live birth or who was pregnant at the time of the survey.

\subsubsection{Independent Variables}

The independent variables included: age of the respondent at the time of first pregnancy, type of residence, educational level, literacy, religion, economic status, union/marital status, and sex of the head of household (who makes the decisions in household). Variables related to access to information (for example, frequency of reading newspaper or magazine, listening to radio, and watching television) were also included, as were variables related to reproductive health (including knowledge of family planning (FP) methods, ovulatory cycle, sources of condoms, perceived ability to acquire condoms, and use of contraceptive methods).

\subsubsection{Covariates}

Economic status was adjusted for given its influence on other variables. In Rwanda, households are categorized according to their economic status via a national, standardized method called Ubudehe (Ministry of Local Government 
(MINALOC) Rwanda, 2016).

\subsection{Data Analysis Procedure}

Descriptive statistics were used to summarize teenage pregnancy status according to social and demographic characteristics. Pearson's chi-square test was used to test associations between teenage pregnancy and the independent variables. Variables in the bivariate analysis were considered to be statistically significant if the P-value was $<0.10$. All variables found significant in the bivariate analysis were used in multivariate analysis. Multivariate analysis was conducted using backward stepwise logistic regression, removing variables that were not significant at $\mathrm{P}=0.05$ from the full model. Economic status was maintained in the reduced model to adjust for its influence on other variables. Odds Ratio (OR), 95\% Confidence Interval (CI) and P-value were reported. All statistical analyses were conducted using STATA version 14.2 (StataCorp Lakeway Drive College Station, Texas).

\section{Results}

\subsection{Description of Demographic Characteristics of Study Participants}

Table 1 shows the demographic features of the study population. The majority of the study participants were from rural areas $(n=2204,79 \%)$. More than half $(n=1632,59 \%)$ had primary education while $1106(40 \%)$ had secondary or higher education, and only $30(1.1 \%)$ had no education. Of all the participants, $2349(84.9 \%)$ were able to read. Regarding economic status, $942(34 \%)$ were in the poor category, $501(18.1 \%)$ were in the middle category, and $1325(47.9 \%)$ were in the rich category. Approximately $96.2 \%(\mathrm{n}=2662)$ had never been in union/married. The analysis showed $882(31.9 \%)$ had incorrect knowledge on ovulation cycle, $2653(95.8 \%)$ were not using any contraceptive methods, $63(2.3 \%)$ were using contraceptive methods, and $52(1.9 \%)$ were pregnant at the time of the survey. Almost half ( $\mathrm{n}=1332,48.2 \%$ ) reported knowing a source of condoms but not being able to get them if they needed them. Among the 2768 females included in the analysis, 201 (7.3\%) had experienced or were currently experiencing teenage pregnancy.

\subsection{Results of Bivariate Analysis}

Table 1 shows the results of the bivariate analysis. It was found that age at first pregnancy, province of residence, education level, union/marital status, contraceptive use and intention to use, knowledge of condom source and ability to get condoms were significantly associated with teenage pregnancy with $\mathrm{P}<0.001$ each. In addition, literacy $(\mathrm{P}=0.007)$, religion $(\mathrm{P}=0.072)$, economic status $(\mathrm{P}=0.005)$, frequency of reading newspapers or magazines $(\mathrm{P}=0.043)$, frequency of listening to radio $(\mathrm{P}=0.048)$, frequency of watching television $(\mathrm{P}=0.075)$, knowledge of any FP method $(\mathrm{P}=0.083)$, and knowledge of ovulation cycle $(\mathrm{P}=0.003)$ were found to be significantly associated with teenage pregnancy. There was no association between teenage pregnancy and rural versus urban residence or the sex of the head of household.

Table 1. Descriptive and bivariate analysis of teenage pregnancy per background characteristics

\begin{tabular}{|c|c|c|c|c|}
\hline \multicolumn{2}{|l|}{ Variables } & $\begin{array}{l}\text { Teenage } \\
\text { Pregnancy }\end{array}$ & $\begin{array}{l}\text { No teenage } \\
\text { Pregnancy }\end{array}$ & P-value \\
\hline \multicolumn{2}{|c|}{ Sample size (weighted $n=2768$ ) } & $201(7.3 \%)$ & $2567(92.7 \%)$ & NA \\
\hline \multirow{5}{*}{$\begin{array}{l}\text { Age at first } \\
\text { pregnancy }\end{array}$} & $<16$ years $(n=667)$ & $7(1.1 \%)$ & $660(98.9 \%)$ & $<0.001$ \\
\hline & $16(\mathrm{n}=571)$ & $23(4 \%)$ & $548(96 \%)$ & \\
\hline & $17(\mathrm{n}=543)$ & $48(8.8 \%)$ & $495(91.2 \%)$ & \\
\hline & $18(\mathrm{n}=553)$ & $60(10.8 \%)$ & $493(89.2 \%)$ & \\
\hline & $19(n=434)$ & $63(14.6 \%)$ & $371(85.4 \%)$ & \\
\hline \multirow[t]{5}{*}{ Province } & Kigali city $(\mathrm{n}=357)$ & $36(10.2 \%)$ & $321(89.8 \%)$ & $<0.001$ \\
\hline & South $(n=665)$ & $37(5.6 \%)$ & $628(94.4 \%)$ & \\
\hline & West $(n=592)$ & $34(5.8 \%)$ & $558(94.2 \%)$ & \\
\hline & North $(n=525)$ & $26(4.9 \%)$ & $499(95.1 \%)$ & \\
\hline & East $(n=628)$ & $67(10.7 \%)$ & $561(89.3 \%)$ & \\
\hline Type of place of & Urban $(n=564)$ & $44(7.9 \%)$ & $520(92.1 \%)$ & 0.556 \\
\hline
\end{tabular}




\begin{tabular}{|c|c|c|c|c|}
\hline residence & Rural (n=2204) & $157(7.1 \%)$ & $2047(92.9 \%)$ & \\
\hline \multirow{3}{*}{$\begin{array}{l}\text { Educational } \\
\text { attainment }\end{array}$} & Primary $(n=1632)$ & $150(9.2 \%)$ & $1482(90.8 \%)$ & \multirow[t]{3}{*}{$<0.001$} \\
\hline & No education $(\mathrm{n}=30)$ & $4(12.7 \%)$ & $26(87.3 \%)$ & \\
\hline & Secondary $(\mathrm{n}=1106)$ & $48(4.3 \%)$ & $1058(95.7 \%)$ & \\
\hline \multirow[t]{2}{*}{ Literacy } & Cannot read $(n=417)$ & $44(10.6 \%)$ & $373(89.4 \%)$ & \multirow[t]{2}{*}{0.007} \\
\hline & Can read $(n=2349)$ & $157(6.7 \%)$ & $2192(93.3 \%)$ & \\
\hline \multirow[t]{4}{*}{ Religion } & Catholic $(\mathrm{n}=1205)$ & $74(6.1 \%)$ & $1131(93.9 \%)$ & \multirow[t]{4}{*}{0.072} \\
\hline & Protestant $(\mathrm{n}=1195)$ & $102(8.5 \%)$ & $1093(91.5 \%)$ & \\
\hline & Adventist ( $\mathrm{n}=287)$ & $17(5.8 \%)$ & $270(94.1 \%)$ & \\
\hline & Muslim, Jehovah witness, others(n=77) & $9(11.6 \%)$ & $68(88.3 \%)$ & \\
\hline \multirow[t]{3}{*}{ Economic status } & Poor $(\mathrm{n}=942)$ & $89(9.5 \%)$ & $853(90.6 \%)$ & \multirow[t]{3}{*}{0.005} \\
\hline & Middle $(n=501)$ & $37(7.3 \%)$ & $464(92.6 \%)$ & \\
\hline & Rich $(n=1325)$ & $75(5.7 \%)$ & $1250(94.3 \%)$ & \\
\hline \multirow{4}{*}{$\begin{array}{l}\text { Union/ } \\
\text { Marital } \\
\text { Status }\end{array}$} & Never in union $(\mathrm{n}=2662)$ & $110(4.1 \%)$ & $2552(95.9 \%)$ & \multirow[t]{4}{*}{$<0.001$} \\
\hline & in Overall $(\mathrm{n}=106)$ & $91(85.9 \%)$ & $15(14.2 \%)$ & \\
\hline & Before 1st pregnancy & $40(43.9 \%)$ & - & \\
\hline & When pregnant or after & $51(56 \%)$ & - & \\
\hline \multirow{3}{*}{$\begin{array}{l}\text { Frequency of } \\
\text { reading newspaper } \\
\text { or magazine }\end{array}$} & Not at all $(n=1774)$ & $145(8.2 \%)$ & $1629(91.8 \%)$ & \multirow[t]{3}{*}{0.043} \\
\hline & Less than once a week $(n=725)$ & $44(6.1 \%)$ & $681(93.9 \%)$ & \\
\hline & At least once a week $(n=265)$ & $11(4.3 \%)$ & $254(95.8 \%)$ & \\
\hline \multirow{3}{*}{$\begin{array}{l}\text { Frequency of } \\
\text { listening to radio }\end{array}$} & Not at all $(n=325)$ & $31(9.7 \%)$ & $294(90.5 \%)$ & \multirow[t]{3}{*}{0.048} \\
\hline & Less than once a week $(n=574)$ & $50(8.8 \%)$ & $524(91.3 \%)$ & \\
\hline & At least once a week $(n=1866)$ & $119(6.4 \%)$ & $1747(93.6 \%)$ & \\
\hline \multirow{3}{*}{$\begin{array}{l}\text { Frequency } \\
\text { watching } \\
\text { television }\end{array}$} & Not at all $(n=1292)$ & $110(8.5 \%)$ & $1182(91.5 \%)$ & \multirow[t]{3}{*}{0.075} \\
\hline & Less than once a week $(n=880)$ & $59(6.7 \%)$ & $821(93.3 \%)$ & \\
\hline & At least once a week $(n=590)$ & $33(5.6 \%)$ & $557(94.4 \%)$ & \\
\hline \multirow{2}{*}{$\begin{array}{l}\text { Knowledge of FP } \\
\text { methods }\end{array}$} & Knows no method $(\mathrm{n}=47)$ & $1(1.6 \%)$ & $46(98.4 \%)$ & \multirow[t]{2}{*}{0.083} \\
\hline & Knows any method $(\mathrm{n}=2721)$ & $200(7.4 \%)$ & $2521(92.6 \%)$ & \\
\hline \multirow{3}{*}{$\begin{array}{l}\text { Ovulatory cycle } \\
\text { knowledge }\end{array}$} & Correct knowledge $(\mathrm{n}=507)$ & $32(6.3 \%)$ & $475(93.7 \%)$ & \multirow[t]{3}{*}{0.003} \\
\hline & Possible correct knowledge $(n=1377)$ & $124(9 \%)$ & $1253(91 \%)$ & \\
\hline & Incorrect knowledge $(\mathrm{n}=882)$ & $45(5.1 \%)$ & $837(94.9 \%)$ & \\
\hline \multirow{3}{*}{$\begin{array}{ll}\text { Use } & \text { of } \\
\text { contraceptive }\end{array}$} & Not using contraceptive $(n=2653)$ & $98(3.7 \%)$ & $2555(96.3 \%)$ & \multirow[t]{3}{*}{$<0.001$} \\
\hline & Using contraceptive $(\mathrm{n}=63)$ & $51(81.8 \%)$ & $12(19 \%)$ & \\
\hline & Currently pregnant $(\mathrm{n}=52)$ & $52(100 \%)$ & - & \\
\hline \multirow{2}{*}{$\begin{array}{l}\text { Sex of household } \\
\text { head }\end{array}$} & Male $(\mathrm{n}=1830)$ & $132(7.2 \%)$ & $1698(92.8 \%)$ & \multirow[t]{2}{*}{0.871} \\
\hline & Female $(\mathrm{n}=938)$ & $69(7.4 \%)$ & $869(92.6 \%)$ & \\
\hline \multirow{3}{*}{$\begin{array}{l}\text { Knowledge of } \\
\text { condom source } \\
\text { and ability to get it }\end{array}$} & $\begin{array}{l}\text { Know the condom source/can get it } \\
(n=1012)\end{array}$ & $49(4.8 \%)$ & $963(95.2 \%)$ & \multirow[t]{3}{*}{$<0.001$} \\
\hline & $\begin{array}{l}\text { Know the condom source/cannot get it } \\
(\mathrm{n}=1332)\end{array}$ & $135(10.2 \%)$ & $1197(89.9 \%)$ & \\
\hline & $\begin{array}{l}\text { Don't know any condom source } \\
(\mathrm{n}=417)\end{array}$ & $17(4.1 \%)$ & $400(95.9 \%)$ & \\
\hline
\end{tabular}




\subsection{Results of Multivariate Analysis}

As Table 2 shows, age, education level, union/marital status, and use of contraceptive method were found as risk factors for teenage pregnancy after adjusting for economic status.

Those who were 17 years old $(\mathrm{OR}=7.04,95 \% \mathrm{CI}$ : 2.67 - 18.58, $\mathrm{P}<0.001), 18$ years old $(\mathrm{OR}=3.78,95 \% \mathrm{CI}: 1.36$ $10.47, \mathrm{P}=0.011)$, and 19 years old $(\mathrm{OR}=3.85,95 \% \mathrm{CI}$ : $1.34-11.01, \mathrm{P}=0.012)$ were more likely to have a teenage pregnancy compared to those who were less than 16 years old.

Those who had secondary or higher education were less likely to have a teenage pregnancy $(\mathrm{OR}=0.36,95 \% \mathrm{CI} 0.22$ $0.61, \mathrm{P}<0.001)$ compared to those with primary education, but there was no significant difference between those with primary education and those with no education $(\mathrm{OR}=0.73,95 \% \mathrm{CI}: 0.22-2.46, \mathrm{P}=0.613)$.

Those who had ever been in union (married) $(\mathrm{OR}=45.9,95 \% \mathrm{CI}: 21.34-98.73, \mathrm{P}<0.001)$ were more likely to have a teenage pregnancy compared to those who had never been in union. Those who were using a contraceptive method were more likely to have a teenage pregnancy compared to those who were not (OR=68.9, 95\%CI: $29.49-160.80$, $\mathrm{P}<0.001)$. Religious affiliations, province of residence, literacy, knowledge of a condom source and ability to access it, frequency of reading newspapers/magazines, listening to radio, and watching television were not significant risk factors for teenage pregnancies.

Table 2. Results of multivariate analysis (Logistic Regression) on risk factors associated with teenage pregnancy

\begin{tabular}{|c|c|c|c|c|c|c|}
\hline \multirow[t]{2}{*}{ Variables } & \multicolumn{3}{|c|}{ Full model } & \multicolumn{3}{|c|}{ Reduced model } \\
\hline & OR & $95 \% \mathrm{CI}$ & $P$ value & OR & $95 \% \mathrm{CI}$ & P value \\
\hline \multicolumn{7}{|c|}{ Age at first pregnancy } \\
\hline$<16$ years & 1 & & & 1 & & \\
\hline 16 & 2.34 & {$[0.81-6.73]$} & 0.116 & 2.62 & {$[0.93-7.41]$} & 0.069 \\
\hline 17 & 6.22 & {$[2.41-16.04]$} & $<0.001$ & 7.04 & {$[2.67-18.58]$} & $<0.001$ \\
\hline 18 & 3.35 & [1.22 - 9.19] & 0.019 & 3.78 & [1.36 - 10.47] & 0.011 \\
\hline 19 & 3.4 & {$[1.21-9.55]$} & 0.020 & 3.85 & {$[1.34-11.01]$} & 0.012 \\
\hline \multicolumn{7}{|l|}{ Province } \\
\hline Kigali city & 1 & & & & & \\
\hline South & 1.05 & {$[0.44-2.49]$} & 0.920 & & & \\
\hline West & 1.36 & {$[0.56-3.30]$} & 0.498 & & & \\
\hline North & 0.79 & {$[0.31-2.04]$} & 0.626 & & & \\
\hline East & 1.59 & {$[0.65-3.84]$} & 0.307 & & & \\
\hline \multicolumn{7}{|c|}{ Educational attainment } \\
\hline Primary & 1 & & & 1 & & \\
\hline No education & 0.52 & {$[0.13-2.11]$} & 0.361 & 0.73 & {$[0.22-2.46]$} & 0.613 \\
\hline Secondary & 0.37 & {$[0.21-0.67]$} & 0.001 & 0.36 & {$[0.22-0.61]$} & $<0.001$ \\
\hline \multicolumn{7}{|l|}{ Literacy } \\
\hline Cannot read & 1 & & & & & \\
\hline Can read & 0.83 & {$[0.41-1.68]$} & 0.611 & & & \\
\hline \multicolumn{7}{|l|}{ Religion } \\
\hline Catholic & 1 & & & & & \\
\hline Protestant & 1.16 & [0.71 - 1.90] & 0.547 & & & \\
\hline Adventist & 1 & {$[0.38-2.63]$} & 0.997 & & & \\
\hline
\end{tabular}




\begin{tabular}{lllllll}
\hline $\begin{array}{l}\text { Muslim - Jehovah witness - } \\
\text { Others }\end{array}$ & 2.55 & {$[0.91-7.12]$} & 0.074 & & & \\
\hline Economic Status & & & & & & \\
\hline Poor & 1 & & & 1 & & \\
\hline Middle & 0.57 & {$[0.29-1.13]$} & 0.109 & 0.6 & {$[0.30-1.18]$} & 0.136 \\
\hline Rich & 0.61 & {$[0.34-1.08]$} & 0.089 & 0.65 & {$[0.39-1.08]$} & 0.097 \\
\hline Union/Marriage status & & & & & & \\
\hline Never in union & 1 & & 1 & & \\
\hline Ever in union & 43.1 & {$[19.10-97.31]$} & $<0.001$ & 45.9 & {$[21.34-98.73]$} & $<0.001$ \\
\hline
\end{tabular}

Frequency of reading newspaper or magazine

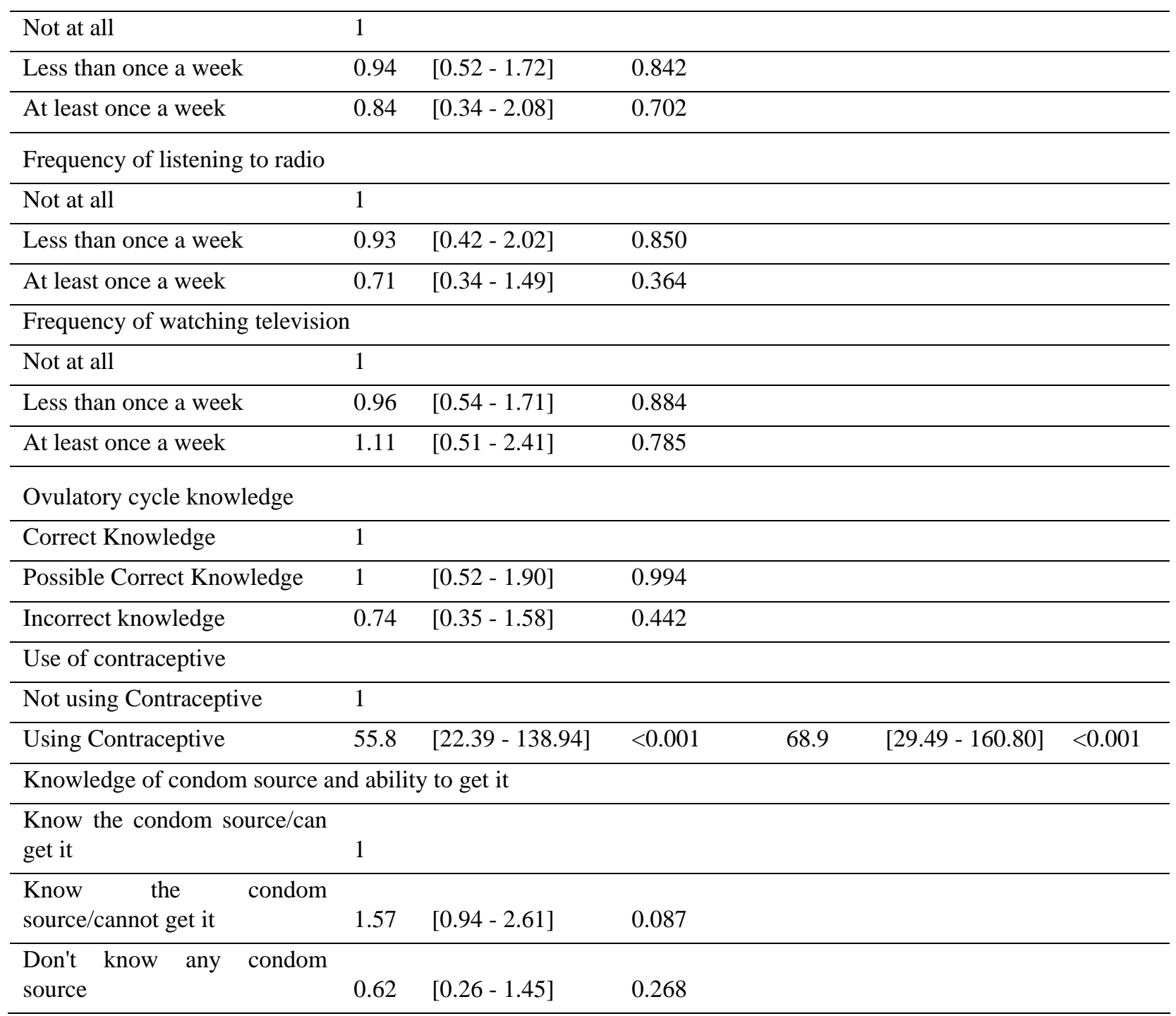

\section{Discussion}

The data of DHS 2014/2015 showed the prevalence of teenage pregnancy in Rwanda was $7.3 \%$ in 2015, which is lower than many neighboring countries like Tanzania (26.7\%), Uganda (24.8\%), and Kenya (18.1\%) and was similar to the prevalence in Burundi (8.3\%) (DHS Program - ICF International, 2018). However, the fact that this rate was increased from 2005 indicates the need for stakeholders to understand and address the problem. 
This analysis found that teenage women with secondary education were less likely to have pregnancy. This result is similar to other studies in some other African countries (Ayele, 2013; Odimegwu \& Mkwananzi, 2016; Rosenberg et al., 2015). Although many studies have found such an association, a causal relationship cannot be definitively established. Some reasonable explanations include that women delay marriage when studying; they may also have improved access to sexual and reproductive health information when they are in schools and therefore be more likely to make informed decisions and less likely to get pregnant (UNFPA, 2013a). However, it could be that women who get pregnant before they reach secondary school are not able to complete their education because of pregnancy. Further research is needed to understand the sequencing. Regardless of whether education reduces teen pregnancy or teen pregnancy limits access to secondary education, one major benefit of education is that it gives teenagers access to information. Studies have shown the importance of providing teenagers with sexual and reproductive health information in preventing teen pregnancy (Stanger-Hall \& Hall, 2011; Sychareun et al., 2018).

The results of our analysis found that access to information through mass media channels like newspaper, radio, and television was not associated with teenage pregnancies. In Rwanda, the most common form of mass media is radio. Radios have more than 98\% national coverage in Rwanda and more than 60\% of Rwandans listen to the radio (National Institute of Statistics of Rwanda (NISR), Ministry of Health (MOH) [Rwanda], 2015; Rwanda Governance Board, 2016). However, we cannot be sure radio is the most common form of mass media for teenagers. Regardless, there have been no mandated or regular sexual or reproductive health information broadcasted on radio. In Rwanda, several behaviorial modification interventions are implemented by community health workers to disseminate information via community events (Abbott, Mutesi, Tuyishime, \& Rwirahira, 2014; Haver, Brieger, Zoungrana, Ansari, \& Kagoma, 2015). Community health workers can reach people living in rural areas where mass media cannot. In addition, community health workers are mandated to provide sexual and reproductive health to the communities, which may be more effective than relying on mass media. Studies should explore how to best use mass media to disseminate health information.

Numerous studies, including our bivariate analysis, have found an association between economic status and teenage pregnancy (Christofides et al., 2014; Neal et al., 2015). Economic status should always be considered when designing programs as it influences access to education and health services, and so should the power of decision-making (Briggs \& Brownell, 2007; UNFPA, 2015). In Rwanda, all families were categorized according to their household income and properties. Many teenagers in Rwanda are unemployed and depend on their parents financially. It is a reasonable assumption that their economic status is reflected by the household economic status; however, the further investigation is needed to understand the actual relationship between teenage pregnancies and their individual economic status.

Our analysis showed the odds of getting pregnant was higher for those using contraceptives than those who did not. At the first glance, this result seems counter-intuitive. Upon further analysis, however, we found that the 51 individuals with teenage pregnancy who reported using contraceptive methods all started using them after delivering their first child, meaning that $100 \%$ of the teenage pregnancies occurred when contraceptives were not used. This finding also suggests that having a previous pregnancy prompted teenagers to start using contraceptives to prevent unwanted pregnancy, similar to a study conducted in South Africa (Christofides et al., 2014). While pregnancy cannot be used as a protective factor to future pregnancy, the evidence suggested that providing information of contraceptives to teenagers at early age is important.

In addition, while improving access to contraceptives among teenagers is proven to be effective in addressing unwanted pregnancies, many teenagers still do not have access to a consistent source of contraceptives (Chandra-Mouli et al., 2014; Kapito, Kazembe, Maluwa, Malata, \& Odland, 2012; WHO, 2012). Our analysis prompts us to suggest that programs to provide contraceptive information and make contraceptives accessible to teenagers at early age can be key to reduce teenage pregnancy.

Age was also among the significant risk factors for teenage pregnancies. In many countries, adolescents become sexually active at a young age (Chandra-Mouli et al., 2014; Ministry of Health - Rwanda, 2011). The earlier adolescents start having sex, the more likely they are to have higher number of sexual partners when they became older (O'Donnell, O'Donnell, \& Stueve, 2001). Combine that with their limited access to contraceptive and they are more likely to have frequent unprotected sex and associated health risks (Ashenhurst, Wilhite, Harden, \& Fromme, 2017; Senn \& Carey, 2011; UNFPA, 2013b; WHO, 2011).

Our findings suggest the importance of providing access to appropriate sexual education and different options of contraceptives to youths to prevent teen pregnancy. Many current programs only emphasize abstinence, as many parents and policymakers fear that availing reproductive health services to adolescents may actually encourage them 
to have sex (UNFPA, 2013b). However, studies have found that availing reproductive health services to youths is not associated with an increase in sexual activity (Advocates for Youth, 2008; Secura, Adams, Buckel, Zhao, \& Peipert, 2014) and the abstinence-only education is ineffective in reducing teenage pregnancies (DiCenso et al., 2002; Kohler et al., 2008; Oringanje et al., 2016; Stanger-Hall \& Hall, 2011).

Our study also found that teenage marriage is an important risk factor for teenage pregnancies, as one might assume. Similar findings have been generated by studies conducted in other LMIC settings including the Philippines, Namibia, Malawi and some East African countries (Eloundou-Enyegue \& Magazi, 2011; Kapito et al., 2012; Natividad, 2013; Neal et al., 2015; UNFPA, 2013a). Interestingly, our further analysis showed that only $43 \%$ of those reported they were in union were actually in union before getting pregnant; the 53\% already had pregnant when they became in union. We cannot confirm if the marriage was the result of the pregnancy, but it is possible, as other studies have shown, that while teenage marriages often result from parental arrangements or community traditions, they may also occur as a result of unwanted pregnancy (Natividad, 2013; UNFPA, 2013b).

Regardless the intention, teenage marriages have many negative consequences on women's health as well as on society in general. Evidence suggests that married teenagers experience increased maternal mortality, higher school dropout rates, more psychological problems, and additional economic and social challenges (Paranjothy, Broughton, Adappa, \& Fone, 2009; UNFPA, 2013b). Acknowledging the gravity of the issue, many countries consider marriage of teenagers below 18 years old as human violence or abuse (United Nations Children's Fund, 2014). Teenage marriages, even when sparked by unexpected pregnancy, should be discouraged. Stakeholders from health sectors, local authorities, civil societies and the communities must work collaboratively to promote parental behavioral change and enforce laws and policies to discourage teenage marriages.

The findings of this study must be viewed in the light of some limitations. Because it analyzed a secondary dataset, this study was not able to examine all factors potentially associated with teenage pregnancy that were not collected by the DHS. Qualitative studies could contribute a deeper understanding of other factors related to beliefs, attitudes and practices prevalent in communities and their influence on teenage pregnancies. There is also a need to evaluate strategies and interventions that aim to reduce teenage pregnancies to understand their impact and effectiveness, in order to inform design and scale up.

\section{Conclusion}

This study highlighted that when designing programs and policies to address teenage pregnancy, policy makers should consider programs to keep girls in schools, at least up to secondary level. Furthermore, sexual and reproductive health programs should not only emphasize abstinence. Ensuring that teenagers have access to reproductive health information can help them to make informed choices. Furthermore, improving their access to a range of reliable contraceptive methods at early age should be encouraged.

Stakeholders and policy makers must acknowledge and discourage teenage marriage, promoting collaborative interventions to engage communities in order to change cultural norm and modify parents' behaviors related to teenage marriages. Utilizing community health workers (CHWs) to prevent teenage pregnancy is also encouraged, as CHWs can reach people living in rural areas where mass media cannot.

This study served is the starting point for further research on an important public health issue in Rwanda. Deeper understanding of the beliefs, attitudes and practices in communities and their influences on teenage pregnancies can help further identify the root causes and risk factors of teenage pregnancy. Finally, it is necessary to further evaluate the strategies and interventions that aim to reduce teenage pregnancies in order to understand their impact and effectiveness, improving design and facilitating effective scale-up.

\section{References}

Abbott, P., Mutesi, L., Tuyishime, C., \& Rwirahira, J. (2014). Reproductive and Sexual Health in Rwanda: A Review of the Literature, Legal and Policy Framework. https://doi.org/10.13140/RG.2.1.3460.7520

Advocates for Youth. (2008). Science and success. Second edition. Sex education and other programs that work to prevent teen pregnancy, HIV and sexually transmitted infections. TT. Retrieved from http://www.advocatesforyouth.org/publications/ScienceSuccess.pdf

Ajala, A. O. (2014). Factors associated with teenage pregnancy and fertility in Nigeria. ISSN, 5(2), 2222-1700. Retrieved from www.iiste.org 
Ashenhurst, J. R., Wilhite, E. R., Harden, K. P., \& Fromme, K. (2017). Number of Sexual Partners and Relationship Status Are Associated With Unprotected Sex Across Emerging Adulthood. Archives of Sexual Behavior, 46(2), 419-432. https://doi.org/10.1007/s10508-016-0692-8

Ayele, W. M. (2013). Differentials of early teenage pregnancy in Ethiopia, 2000, and 2005. DHS Working Papers No. 90. Retrieved from http://dhsprogram.com/pubs/pdf/WP90/WP90.pdf

Binagwaho, A., Farmer, P. E., Nsanzimana, S., Karema, C., Gasana, M., de Dieu Ngirabega, J., ... Drobac, P. C. (2014). Rwanda 20 years on: investing in life. Lancet, 384(9940), 371-375. https://doi.org/10.1016/S0140-6736(14)60574-2

Brace, A. M., Hall, M., Eatman, J., \& Tucker, N. (2008). Social, Economic and Health Costs of Unintended Teen Pregnancy: The Circle of Care Intervention Program in Troup County, Georgia. Journal of the Georgia Public Health Association, 1(1), 33-46.

Briggs, G., \& Brownell, M. (2007). Teen Mothers and Socioeconomic Status, The Chicken-Egg Debate. Journal of the Motherhood Initiative for Research and Community Involvement, 9(1), 62-74.

Chandra-Mouli, V., McCarraher, D. R., Phillips, S. J., Williamson, N. E., \& Hainsworth, G. (2014). Contraception for adolescents in low and middle income countries: needs, barriers, and access. Reproductive Health, 11(1), 1. https://doi.org/10.1186/1742-4755-11-1

Christofides, N. J., Jewkes, R. K., Dunkle, K. L., McCarty, F., Jama Shai, N., Nduna, M., \& Sterk, C. (2014, June). Risk factors for unplanned and unwanted teenage pregnancies occurring over two years of follow-up among a cohort of young South African women. Global Health Action, 7, 23719. https://doi.org/10.3402/gha.v7.23719

Coelho, F. M. da C., Pinheiro, R. T., Silva, R. A., Quevedo, L. de Á., Souza, L. D. de M., Castelli, R. D., ... Pinheiro, K. A. T. (2013). Major depressive disorder during teenage pregnancy: Socio-demographic, obstetric and psychosocial correlates. Revista Brasileira de Psiquiatria, 35(1), 51-56. https://doi.org/10.1016/j.rbp.2012.03.006

DHS Program - ICF International. (2018). The DHS Program: Demographic and Health Surveys - Stata Compiler. Retrieved December 10, 2018, from http://www.statcompiler.com/en/

DiCenso, A., Guyatt, G., Willan, A., \& Griffith, L. (2002). Interventions to reduce unintended pregnancies among adolescents: systematic review of randomised controlled trials. BMJ (Clinical Research Ed.), 324(7351), 1426. Retrieved from https://www.ncbi.nlm.nih.gov/pubmed/12065267

Eloundou-Enyegue, P. M., \& Magazi, S. (2011). Teenage Pregnancy in Kavango Region.

Ertem, M., Saka, G., Ceylan, A., Değer, V., \& Çiftçi, S. (2008). The factors associated with adolescent marriages and outcomes of adolescent pregnancies in Mardin Turkey. Journal of Comparative Family Studies.

Ganchimeg, T., Ota, E., Morisaki, N., Laopaiboon, M., Lumbiganon, P., Zhang, J., .. Mori, R. (2014). Pregnancy and childbirth outcomes among adolescent mothers: a World Health Organization multicountry study. BJOG: An International Journal of Obstetrics and Gynaecology. https://doi.org/10.1111/1471-0528.12630

Haver, J., Brieger, W., Zoungrana, J., Ansari, N., \& Kagoma, J. (2015). Experiences engaging community health workers to provide maternal and newborn health services: Implementation of four programs. International Journal of Gynecology and Obstetrics. https://doi.org/10.1016/j.ijgo.2015.03.006

Iwu, R. U., Onoja, A. I., Ijioma, B. C., Ngumah, M. O., \& Egeruoh, A. S. (2011). The integration of sexuality education in secondary school Biology curriculum for sustainable development: Teachers perception. International Journal of Science and Technology Education Research,2(4), 62-66.

Kanku, R. T., \& Marsh. (2015, August). Attitudes, perceptions and understanding amongst teenagers regarding teenage pregnancy, sexuality and contraception in Taung. South African Family Practice, 52, 563-572. https://doi.org/10.1080/20786204.2010.10874048

Kapito, E., Kazembe, A., Maluwa, A., Malata, A., \& Odland, J. O. (2012). Attitudes towards contraceptive use among schooling adolescents in Malawi. Journey of Research InNursing and Midwifery, 1(4), 47-55.

Kohler, P. K., Manhart, L. E., \& Lafferty, W. E. (2008). Abstinence-Only and Comprehensive Sex Education and the Initiation of Sexual Activity and Teen Pregnancy. Journal of Adolescent Health, 42(4), 344-351. https://doi.org/10.1016/j.jadohealth.2007.08.026 
Loto, O. M., Ezechi, O. C., Kalu, B. K. E., Loto, A. B., Ezechi, L. O., \& Ogunniyi, S. O. (2004). Poor obstetric performance of teenagers: Is it age- or quality of care-related?. Journal of Obstetrics and Gynaecology. https://doi.org/10.1080/01443610410001685529

Manzi, A., Munyaneza, F., Mujawase, F., Banamwana, L., Sayinzoga, F., Thomson, D. R., ... Hedt-Gauthier, B. L. (2014). Assessing predictors of delayed antenatal care visits in Rwanda: a secondary analysis of Rwanda demographic and health survey 2010. BMC Pregnancy and Childbirth, 14, 290. https://doi.org/10.1186/1471-2393-14-290

Ministry of Health - Rwanda. (2011). Rapid Assessment of Adolescent Sexual Reproductive Health Programs, Services and Policy Issues in Rwanda. Kigali. Retrieved from http://pdf.usaid.gov/pdf_docs/PA00J35H.pdf

Ministry of Local Government (MINALOC) Rwanda. (2016). Revised Ubudehe Categories are Out. Retrieved January $10, \quad 2019, \quad$ from http://www.minaloc.gov.rw/index.php?id=469\&tx_ttnews\%5Btt_news\%5D=461\&cHash=73a0ab3f4bcf956765 ddc0eb2b88b538

Moni, S. A., Nair, M. K. C., \& Devi, R. S. (2013). Pregnancy among unmarried adolescents and young adults. Journal of Obstetrics and Gynecology of India, 63(1), 49-54. https://doi.org/10.1007/s13224-012-0244-7

Mukabutera, A., Thomson, D. R., Hedt-Gauthier, B. L., Basinga, P., Nyirazinyoye, L., \& Murray, M. (2016). Risk factors associated with underweight status in children under five: an analysis of the 2010 Rwanda Demographic Health Survey (RDHS). BMC Nutrition, 2(1), 40. https://doi.org/10.1186/s40795-016-0078-2

National Institute of Statistics of Rwanda (NISR), Ministry of Health (MOH) [Rwanda], \& I. I. (2015). Rwanda Demographic and Health Survey 2014-15 Final Report. Rockville, Maryland, USA: NISR, MOH, and ICF International.

National Institute of Statistics of Rwanda. (2014). Fourth Population and Housing Census, Rwanda, 2012 Final Results, Main indicators report. Kigali. Retrieved from http://www.lmis.gov.rw/scripts/publication/reports/Fourth Rwanda Population and Housing Census_Housing.pdf

Natividad, J. (2013). Teenage Pregnancy in the Philippines: Trends, Correlates and Data Sources. Journal of the ASEAN Federation of Endocrine Societies, 28(1), 30-37. https://doi.org/10.15605/jafes.028.01.07

Ndahindwa, V., Kamanzi, C., Semakula, M., Abalikumwe, F., Hedt-Gauthier, B., \& Thomson, D. R. (2014). Determinants of fertility in Rwanda in the context of a fertility transition: a secondary analysis of the 2010 Demographic and Health Survey. Reproductive Health, 11(1), 87. https://doi.org/10.1186/1742-4755-11-87

Neal, S. E., Chandra-Mouli, V., \& Chou, D. (2015). Adolescent first births in East Africa: disaggregating characteristics, trends and determinants. Reproductive Health, 12(1), 13. https://doi.org/10.1186/1742-4755-12-13

O’Donnell, L., O’Donnell, C. R., \& Stueve, A. (2001). Early Sexual Initiation and Subsequent Sex-Related Risks among Urban Minority Youth: The Reach for Health Study. Family Planning Perspectives. https://doi.org/10.2307/3030194

Odimegwu, C., \& Mkwananzi, S. (2016). Factors associated with teen pregnancy in sub-Saharan Africa: a multi-country cross-sectional study: original research article. African Journal of Reproductive Health, 20(3), 94-107. Retrieved from http://journals.co.za/content/ajrh/20/3/EJC195767

Okigbo, C. C., \& Speizer, I. S. (2015). Determinants of Sexual Activity and Pregnancy among Unmarried Young Women in Urban Kenya: A Cross-Sectional Study. Plos One, 10(6), e0129286. https://doi.org/10.1371/journal.pone.0129286

Oringanje, C., Meremikwu, M. M., Eko, H., Esu, E., Meremikwu, A., \& Ehiri, J. E. (2016). Interventions for preventing unintended pregnancies among adolescents. Cochrane Database of Systematic Reviews, (2). https://doi.org/10.1002/14651858.CD005215.pub3

Paranjothy, S., Broughton, H., Adappa, R., \& Fone, D. (2009). Teenage pregnancy: who suffers? Archives of Disease in Childhood, 94(3), 239-245. https://doi.org/10.1136/adc.2007.115915

Rosenberg, M., Pettifor, A., Miller, W. C., Thirumurthy, H., Emch, M., Afolabi, S. A., ... Tollman, S. (2015). Relationship between school dropout and teen pregnancy among rural South African young women. International Journal of Epidemiology, 44(3), 928-936. https://doi.org/10.1093/ije/dyv007 
Rutaremwa, G. (2013). Factors Associated with Adolescent Pregnancy and Fertility in Uganda : Analysis of the 2011 Demographic and Health Survey Data. American Journal of Sociological Research, 3(2), 30-35.

Rwanda Governance Board. (2016). The status of media Houses in Rwanda. Retrieved from http://rgb.rw/fileadmin/templates/ds/PDF_documents/The_status_of_media_Houses_in_RWANDA.pdf

Secura, G. M., Adams, T., Buckel, C. M., Zhao, Q., \& Peipert, J. F. (2014). Change in sexual behavior with provision of no-cost contraception. Obstetrics and Gynecology, 123(4), 771-776. https://doi.org/10.1097/AOG.0000000000000184

Senn, T. E., \& Carey, M. P. (2011). Age of partner at first adolescent intercourse and adult sexual risk behavior among women. Journal of Women's Health (2002), 20(1), 61-66. https://doi.org/10.1089/jwh.2010.2089

Stanger-Hall, K. F., \& Hall, D. W. (2011). Abstinence-only education and teen pregnancy rates: Why we need comprehensive sex education in the U.S. PLoS ONE, 6(10), 1-11. https://doi.org/10.1371/journal.pone.0024658

Sychareun, V., Vongxay, V., Houaboun, S., Thammavongsa, V., Phummavongsa, P., Chaleunvong, K., \& Durham, J. (2018). Determinants of adolescent pregnancy and access to reproductive and sexual health services for married and unmarried adolescents in rural Lao PDR: a qualitative study. BMC Pregnancy and Childbirth, 18(1), 219. https://doi.org/10.1186/s12884-018-1859-1

The World Bank Group. (2017). GDP per capita (current US\$) Data. Retrieved January 9, 2019, from https://data.worldbank.org/indicator/NY.GDP.PCAP.CD

UNFPA. (2013a). ADOLESCENT PREGNANCY : A Review of the Evidence.

UNFPA. (2013b). Motherhood in Childhood: Facing the Challenge of Adolescent Pregnancy. State of the World Population 2013.

UNFPA. (2015). Girlhood, Not Motherhood - Preventing Adolescent Pregnancy. United Nations Population Fund. Retrieved from www.unfpa.org

United Nations Children's Fund. (2014). A statistical Snapshot of Violence against Adolescent girls. Retrieved from https://www.unicef.org/publications/files/A_Statistical_Snapshot_of_Violence_Against_Adolescent_Girls.pdf

WHO. (2011). Preventing Early Pregnancy and Poor Reproductive Outcomes. WHO Guidelines, 1-208.

WHO. (2012). Preventing early pregnancy and poor reproductive outcomes among adolescents in developing countries: what the evidence says. Guidelines, 2-9. 